\title{
The Professional Geographer
}

\section{Emerging Chinese Cities: Implications for Global Urban Studies}

\section{Fulong Wu}

To cite this article: Fulong Wu (2016) Emerging Chinese Cities: Implications for Global Urban Studies, The Professional Geographer, 68:2, 338-348, DOI: 10.1080/00330124.2015.1099189

To link to this article: http://dx.doi.org/10.1080/00330124.2015.1099189

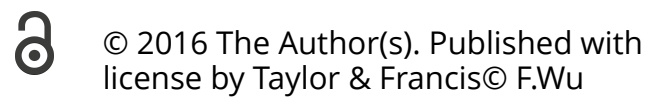

曲 Published online: 16 Nov 2015.

Submit your article to this journal

Џلll Article views: 585

Q View related articles $\longleftarrow$

View Crossmark data $₫$ 


\title{
Emerging Chinese Cities: Implications for Global Urban Studies
}

\author{
Fulong Wu \\ University College London
}

\begin{abstract}
Chinese cities are emerging in multiple senses: They have
created new physical spaces to accommodate the fast urbanization of the country but have also developed new properties and characteristics along with urban transformation. The novelty created by emerging cities in China is not easily covered by Western urban theory. This article examines the dynamism of Chinese urban transformation, especially political economic changes vis-à-vis so-called neoliberalism, and spatial outcomes as diverse and contrasting spaces of formality and informality. Finally, this article speculates on implications for global urban studies.
\end{abstract}

Key Words: Chinese cities, informality, neoliberalism, urban China.

中国城市在多重的意义上正在崛起: 它们创造了崭新的实质空间, 以容纳国家的高速城市化, 但却同时随着城市变迁, 发展出 新的产权及特徵。中国崛起中的城市之创新性, 并无法轻易地以西方城市理论涵盖之。本文检视中国城市变迁的动态, 特别 是相对于所谓的新自由主义的政治经济改变，以及作为多样且截然不同的正式与非正式空间的空间后果。本文最终思考其 对全球城市研究的意涵。关键词: 中国城市, 非正式性, 新自由主义, 中国城市。

Las ciudades chinas están emergiendo en múltiples sentidos: Han creado nuevos espacios físicos para acomodar la rápida urbanización del país, aunque también han desarrollado nuevas propiedades y características junto con la transformación urbana. La novedad generada por las ciudades emergentes de China no se cubre fácilmente con la teoría urbana occidental. Este artículo examina el dinamismo de la transformación urbana china, en especial los cambios económico-políticos vis-a-vis con el así llamado neoliberalismo, y también los resultados espaciales a cual más diversos, y los espacios contrastados de formalidad e informalidad. Finalmente, este artículo especula sobre implicaciones para los estudios urbanos globales. Palabras clave: ciudades chinas, informalidad, neoliberalismo, China urbana.

$\mathrm{C}$ hinese cities are emerging in multiple senses: Physically, they are growing rapidly as a result of fast urbanization and the economic growth of the country. They have received millions of rural migrants. Theoretically speaking, they are emerging because of novel features and properties that cannot be easily described by existing urban theories mainly derived from Western countries. Traditionally the study of Chinese cities followed the category of third world cities. As argued by Dick and Rimmer (1998) in the context of Southeast Asian cities, however, this approach became less appropriate under globalization. Moreover, although Chinese cities share some features with third world cities in their underdeveloped economies and the challenges brought about by urbanization, socialist history since 1949 has created a distinctive political economy and urban spatial structure. On the other hand, the history of socialism did not bring Chinese cities closer to so-called postsocialist cities (Andrusz, Harloe, and Szelenyi 1996), because the economies of cities in Central and Eastern European countries are industrialized and urbanized, whereas China maintained an urbanization level below 20 percent before 1979 (Zhou and Ma 2003). Chinese cities are emerging just like other cities in the Global
South, despite significant differences between them. Because of their complexity and the emergent properties of that complexity, their future is not predefined by existing urban theory; future changes are full of uncertainties and thus can be transformed through active agencies and collective actions. The metaphor of using Chinese cities as a laboratory to observe contemporary urban changes across the planet means that we should be more flexible about the framework of research. The cities are lived experience, too. Research on Chinese cities could have important implications for global urban studies. In this case, the direction of travel in theories is from Shanghai to Los Angeles rather than the application of the Los Angeles School theories (Robinson 2011).

This direction of travel means generating local knowledge for the development of global urban theories, or as "art of being global" (Roy and Ong 2011). Focusing on Chinese cities, this article first reviews the political economic processes underlying urban transformation. A familiar paradigm is neoliberalism, initially developed in the West. In the regional context, another relevant perspective is the "developmental state" developed in East Asia. These two paradigms are quite contradictory regarding the role of the state.

(C) F. Wu

This is an Open Access article distributed under the terms of the Creative Commons Attribution License (http://creativecommons.org/licenses/by/3.0), which permits unrestricted use, distribution, and reproduction in any medium, provided the original work is properly cited. The moral rights of the named author(s) have been asserted. 
The case of Chinese cities reveals that these two seemingly contradictory processes might actually fit together well in the Chinese model of the world factory: the devolution of economic decision making to the urban scale and fiscal recentralization that consolidates the capacity of the state. Land development generates revenues for the local state and at the same time the system is maintained by retaining the power of the central state to appoint local officials. This means promotion on the basis of economic performance. By these specific local mechanisms, local competition states are created. Moreover, development is supported by other necessary institutions, namely, the commodification of housing and the establishment of locally managed land sales, leading to a local development regime that combines entrepreneurialism and the operation of state apparatus, forming a specific form of state entrepreneurialism. As a result, we see the paradoxical coexistence of competitive land bidding as a quite market-oriented behavior together with the prolonging of household registration (bukou) that represents state control. This dynamism of urbanization and growth creates diverse urban spatial forms: suburban "commodity housing" estates built into forms similar to North American gated communities and urban villages converted from former villages in periurban areas. These spatial presentations might be similar to gated communities or master-planned estates, informal settlements, and slums, but they have their own dynamics defined by local contexts. From these dynamics and diverse urban forms, the implications for global urban studies are considered in this article, with reference to the developed knowledge in the north, such as postsuburbia and gated communities (Blakely and Snyder 1997) and social marginalization (Wacquant 2008). Theoretically, the emergence of Chinese cities shows the value and limitation of using neoliberalism to understand emerging Asias.

\section{Dynamism of Chinese Urbanization}

China's market transition started in rural areas. The participation of village cadres in township and village enterprises (TVEs) in the 1980s and early 1990s led to entrepreneurial governance. Oi (1995) described this close association between local state cadres and enterprises as local state corporatism. Wank (1996) used the term clientism to describe the relationship or guanxi between cadres and private business. Participation in the economy of private business brought both personal wealth to managers and taxation to the local government. Y. Q. Huang (2008) argued that these TVEs might be disguised as a collective economy but are actually privately controlled. This was not really corporatism, then, but privatization of rural collective economies. The concept of local state corporatism was invented in the context of rural China, where the power of the state was less developed compared with the cities. When Walder (1995) proposed the thesis of local government as industrial firms, his perspective was more structural or focused on the institutional dynamics of entrepreneurial governance. He emphasized the hardening of the budgets of local government through fiscal reform, which greatly incentivized the endeavors of local government to promote local economies. When real estate became an important sector in Chinese cities after the land and housing reform in the 1990s, Duckett (2001) found the participation of bureaucrats in real estate business, arguing, much like the local state corporatism developed for rural China, that entrepreneurialism had developed in urban China.

Extensive studies have been conducted on the impact of fiscal reform and rising localism. Economists suggest that China operated a de facto economic federalism (Qian and Weingast 1997), which gave rise to the incentives of local economic growth. In 1994, however, the reformed tax system, known as a tax sharing system, hardened the boundary of local taxes, and strengthened the position of the central government in tax collection (Tsui and Wang 2004). The income from land development and sales was given to the local government. Chinese urban studies reveal the transfer of power from the workplace to localities, or the so-called territorialization of land management (Hsing 2006). Subsequently, local governments have participated directly in land and infrastructure development. Recent studies highlight the role of land development in Chinese urbanization and the sale of land to generate revenue. Land finance dominates the overall process and creates local entrepreneurialism (Zhu 2004; Chien 2013; L. Wang 2014). Lin (2014) described land commodification leading to local development due to the rescaling and reshuffling of state power. This is used as "a strategy adopted by the Chinese municipal governments in their contestation of the scaling-up of fiscal power and scaling-down of developmental liabilities and responsibilities" (1832). As a result of these studies, middle-range theories emerged to offer explanations more on the basis of institutional changes in China.

There are differences between local state corporatism and the thesis of the entrepreneurial city. The former sees involvement in market development as necessarily driven by direct personal benefits or engagement with business. The latter follows the theory of urban entrepreneurialism developed in the West and tends to see the change of governance in a more strategic way. There can be more strategic consideration, for example, in using the market to develop global cities (Chien 2013). In geography and urban studies, although the notion of urban entrepreneurialism originated from a more structural interpretation of post-Fordist transformation (Harvey 1989), Jessop and Sum (2000) proposed the concept of the entrepreneurial city and operationalized the concept by defining three aspects, namely pursuing entrepreneurial strategies, creating entrepreneurial discourses, and adopting entrepreneurial actions. Their prototype is 
Hong Kong, but their analogy to the Schumpeterian firm creates a theoretical tension: The city is a polity and in essence does not behave like a firm. Cochrane (2007) warned that "there is also a danger that its mobilization in the analysis of 'entrepreneurialism' in practice may either lead to an exaggeration of the significance of some aspects of the process or to a dismissal of the extent to which particular experiences meet the template" (101). For Shanghai, Wu (2003) adopted the same perspective but rather unintentionally subverted the notion of the entrepreneurial city because the state had been at the center of reglobalizing Shanghai rather than the entrepreneurial city itself. The reason is that the strategy is less entrepreneurial and more structural and strategic, linking with the scale of the nation state that strived to revitalize the Yangtze River delta.

What triggered the transformation toward entrepreneurial governance? Chinese local governments are not allowed to borrow directly from the capital market and hence must resort to an indirect approach through land and infrastructure development. These investments are counted as fixed assets, which can be used to borrow capital from the banking system. Urban development is thus a value-added activity, raising land values. This has happened in an environment in which there has been a general trend of property value inflation. In other words, these properties are capital investments to retain value. Tao et al. (2010) provided a more sophisticated explanation for entrepreneurial-like behavior and explain why local governments have tended to subsidize land and infrastructure for manufacturing investment since the mid-1990s. The local governments supplied cheaper land for industries, even at a cost below that of acquisition, because there was a positive spillover effect on land values in the cities. Industrial development raises the value of commercial and residential land. Real estate development driven by commercial and residential land development thus generates land profits, which belong entirely to local government. Overall economic development also raises sales tax, which is also a local tax. This explanation, although plausible, relies too much on the complex dynamics of the spillover effect. It nevertheless explains the race to the bottom in local development widely observed in Chinese cities (D. Y. R. Yang and Wang 2008; Chien 2013).

Asymmetric political and fiscal concentration and decentralization of economic decision making (Chien and Gordon 2008) are two major features. The central government uses economic performance indicators (especially gross domestic product [GDP] growth rate) to measure and promote local government officials. This has led to so-called GDPism, or a tournament of economic development according to economists. There has been a long tradition in economic explanation for decentralization, such as economic federalism or the "regionally decentralized authoritarian regime" (C. Xu 2011, 1076). Local governments mobilize investment to fund infrastructure development. Development involves different economic sectors (cheaper land for industrial

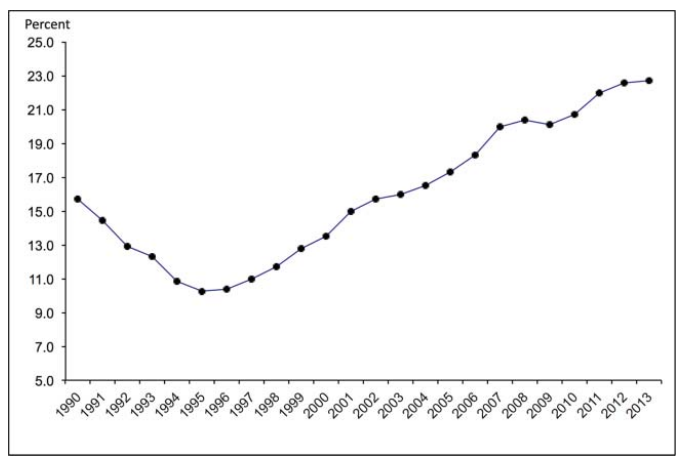

Figure 1 The ratio of national revenue income to gross domestic product in China, 1990-2013. (Color figure available online.)

development while getting returns from real estate) and complex financial innovation (using the state-owned development corporation as the medium for local investment). The result is the need for a more aggressive and involved local state. In terms of the relation between globalization and Chinese urbanization, the national state has its own agenda in articulating globalization. The local state adopted a growth strategy to cope with the potential threat to its power faced with globalization and marketization. There has been a dialectical relation between the national state that is faced with a threat due to complexity and mobility unleashed by economic globalization, but at the same time the process has created an imperative to reinvent its regulatory capacity. Chinese urbanization thus does not follow the logic of global capital but rather the mentality of a developmental state, whose strategy is operationalized at the urban scale through market approaches. This can be seen in suburban development around Beijing, which is driven by state entrepreneurialism (F. Wu and Phelps 2011), orchestrated by the development corporation of the Beijing Economic and Technological Development Zone (ETDZ) at Yizhuang. Rather than a spontaneous cluster of postsuburban businesses at an edge city location, the development of new towns in this case has been under close supervision and strategically planned for the municipality of Beijing to create a new growth pole along the Beijing-Tianjin development corridor.

Fiscal reform has enhanced the ability of the central state to extract revenue (Figure 1). The trajectory of the ratio shows a $\mathrm{V}$ shape, delineating different stages of Chinese economic reform. In the earlier stage, the percentage declined, characteristic of economic devolution and deregulation. The ratio declined from about 27 percent in 1979 to its lowest, 10 percent, in 1995. At that stage, local governments were more inclined to make tax concessions because the costs were borne by the central government. Since the establishment of the tax-sharing system, the ratio has been increasing, up to 20 percent in 2007 and 23 percent in 2012. This reflects the strengthened capacity for fiscal extraction through the operation of the current development regime. 

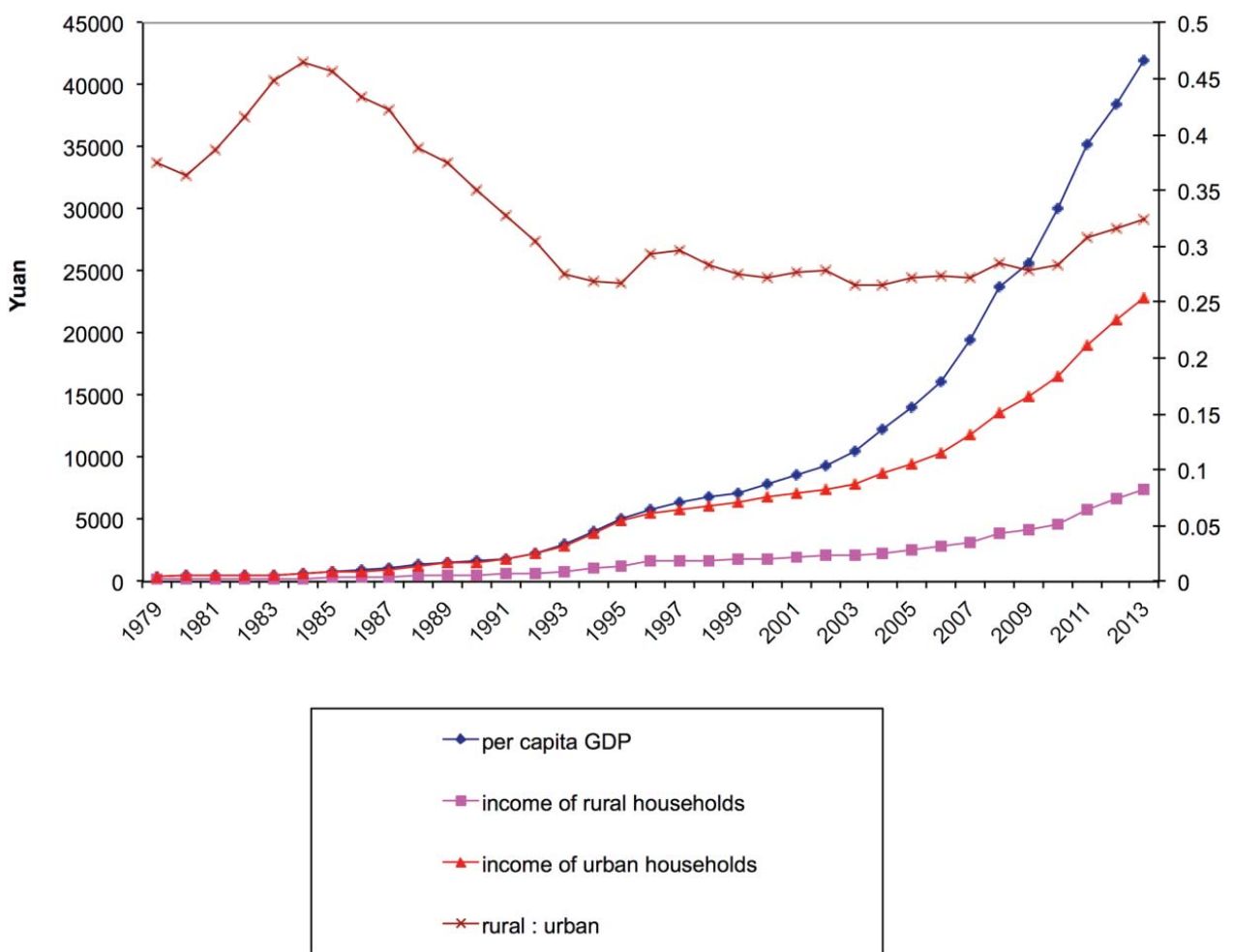

Figure 2 Rural and urban household incomes and gross domestic product in China, 1979-2013. GDP= gross domestic product. (Color figure available online.)

Overall, the development regime was effective in surplus extraction as well as raising GDP. The income of urban households increased significantly but lagged behind GDP growth, with rural households lagging further behind (Figure 2). After the reform shifted into the cities, the income ratio of rural to urban households declined from about 45 percent in 1984 to 27 percent in 2007, closing at 32 percent in 2013. This enlarged income gap between urban and rural households has been accompanied by an overall increase in social inequalities. Migrant workers have become the de facto working poor in the cities. Inequality between rural and urban areas is thus translated into inequalities between different social groups (local urban households vs. migrant workers) inside the cities. The outflow of younger workers from rural areas devastated the rural economy and society, creating social problems of family separation and instability, and leftbehind children in the countryside.

\section{Social Implications and Marginalization}

The preceding dynamics create social implications for Chinese cities. Development is increasingly driven by investment in fixed assets rather than consumption. Household consumption has been a decreasing share of GDP, with its contribution to GDP growth rate also declining in recent years. With the enhanced capacity of both the state and capital in surplus extraction, the return to the production factor of labor is declining. The proportion of wages in GDP declined from 51.5 percent in 2002 to 39.7 percent in 2007 . The ratio of household consumption to GDP similarly declined, from 52 percent in 1981 to 35 percent in 2007 and 36 percent in 2013 (Figure 3). The problem of urban poverty emerged after market-oriented reform, although income levels in general have been increasing (see earlier). The new poor have been created both as laid-off workers and as the working poor of rural migrants (F. Wu 2004; Solinger 2006).

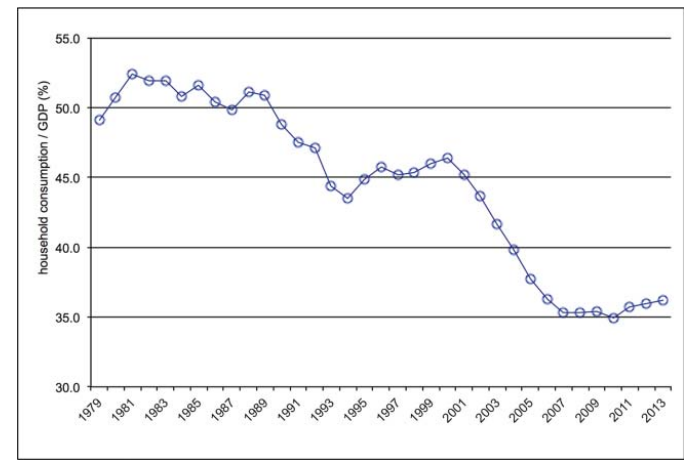

Figure 3 Household income and gross domestic product in China, 1979-2013. GDP = gross domestic product. (Color figure available online.) 
The issue of urban poverty in China is different from advanced marginality, however, in that it is not a case of "outcast ghettos" inhabited by those excluded from the post-Fordist economy (Marcuse 1997; Wacquant 2008). The urban poor have links with the emerging economy of global production, as can be seen from informal workshops and rural migrants as the workforce for these manufacturing industries. They might live in factory-run dormitories (Y.-R. D. Yang 2013) where maintenance is quite strict and disciplined or in urban villages that generate private rental income for local farmers. These villages are living places, small markets, and even small workshops (e.g., the clothing market in Guangzhou) that play a role in global production circulation and networks. To understand this Chinese form of marginalization, it is pertinent to understand local institutions and the historical definition of citizenship. Under state socialism, social welfare provision was associated with workplace affiliation, effectively distinguishing insiders and outsiders in the system. Moreover, rural areas were outside the state realm. These fragmented structures have had different implications for different social groups in the aftermath of market reform.

The rural migrants who were outside the state realm have had to rely on the market provision of social services. In terms of housing, they mostly stay in rental housing in urban villages or factory dormitories (W. Wu 2008). As for the employees of state-owned enterprises, after being laid off, they were transferred from their workplaces to local governments. The system of minimum income support covers those below the minimum income line, but the majority of workers now receive services in commoditized form-as seen in the process of privatization and commodification of health care, education, and housing. The process of marginalization, therefore, is not just a result of economic restructuring and globalization but also a result of the interaction of these macroeconomic processes with local institutions. Urban development and redevelopment under market transition have been a process of expansion and clarification of property rights, but the process has had different impacts on social groups, depending on their status in locally defined institutions. The result is to constrain claims based on citizenship, replacing these with a more local form of provision.

\section{Diverse Spatial Forms}

As can be seen in Chinese urban studies, diverse spatial forms have been generated in the process of market transition (Logan 2008). Housing inequalities and spatial segregation have emerged (Liu, $\mathrm{He}$, and $\mathrm{Wu}$ 2012). Migrant settlements are distributed in the periurban areas (W. Wu 2008). Chinese cities have seen the creation of complex and contrasting urban landscapes. There are formal and master-planned residential enclaves (Pow 2009; L. Zhang 2010; He 2013) and informal settlements developed from rural villages (Tian 2008; F. Wu, Zhang, and Webster 2013). The city proper is developed in a more orderly way, in the form of skyscrapers and high-rise residential buildings. The order of urban areas is created by the legacy of strong state control, especially through state workunits. Land development is more informal in periurban areas, however. As much as one third of new development is in the category of so-called limited property rights (Deng 2009), where farmers developed housing for sale in the housing market without full endorsement of the state in terms of land uses and land development rights, which have to be obtained through competitive bidding in urban land markets.

In southern China, Shantou has seen the appearance of densely mixed rural and urban land uses, resulting from globally driven industrialization (Figure 4). The development of industrial land is mixed with preexisting rural villages, creating severe spatial fragmentation. A novel type of spatial form has been created, known as three in one (san be $y i)$, combining workshop, warehouse, and residence. It creates a convenient place for rural workers to live on site but at the same time creates serious public health and environmental problems. Tranquil rural areas were converted to sites for world factories, but some areas developed into haphazard and polluting familybased workshops, for example, disassembling waste electronic products and extracting their metals. In some larger workshops, factory-run workers' dormitories provide effective accommodation for the influx of workers from rural areas, but at the same time they are subject to the regimes of factory management and dominant overseers. This form of residence dismantled the potential social networks existing among fellow migrants from the same origin of place (Ma and Xiang 1998) and imposed the disciplinary power of capital (Y.-R. D.Yang 2013).

The most widespread form is urban villages, developed through farmers' self-building and the extension of rural villages now encroached on by the city (Tian 2008). Chinese urban informality is derived from urban-rural dualism, in which urban and rural land have been subject to different land systems. Urban land is state-owned, whereas rural land is collectively owned by farmers (J. Xu, Yeh, and Wu 2009; Hsing 2010). In urban areas, a significant proportion was under individual workplaces or "socialist land masters" (Hsing 2006, 2010). In rural areas, though, collective ownership meant that the power of dealing with land development was ambiguous (Zhu 2004). Urban villages can be regarded as Chinese informal settlements (Y. P. Wang, Wang, and Wu 2009). The traditional lax land management and planning control in the countryside is another source of informality (F. Wu, Zhang, and Webster 2013). Service provision in these rural villages is not funded through public finance (Po 2012; F. Wu, Zhang, and Webster 2013). Provision is thus not a welfare delivery but rather a benefit managed by rural collectives. This mode of 


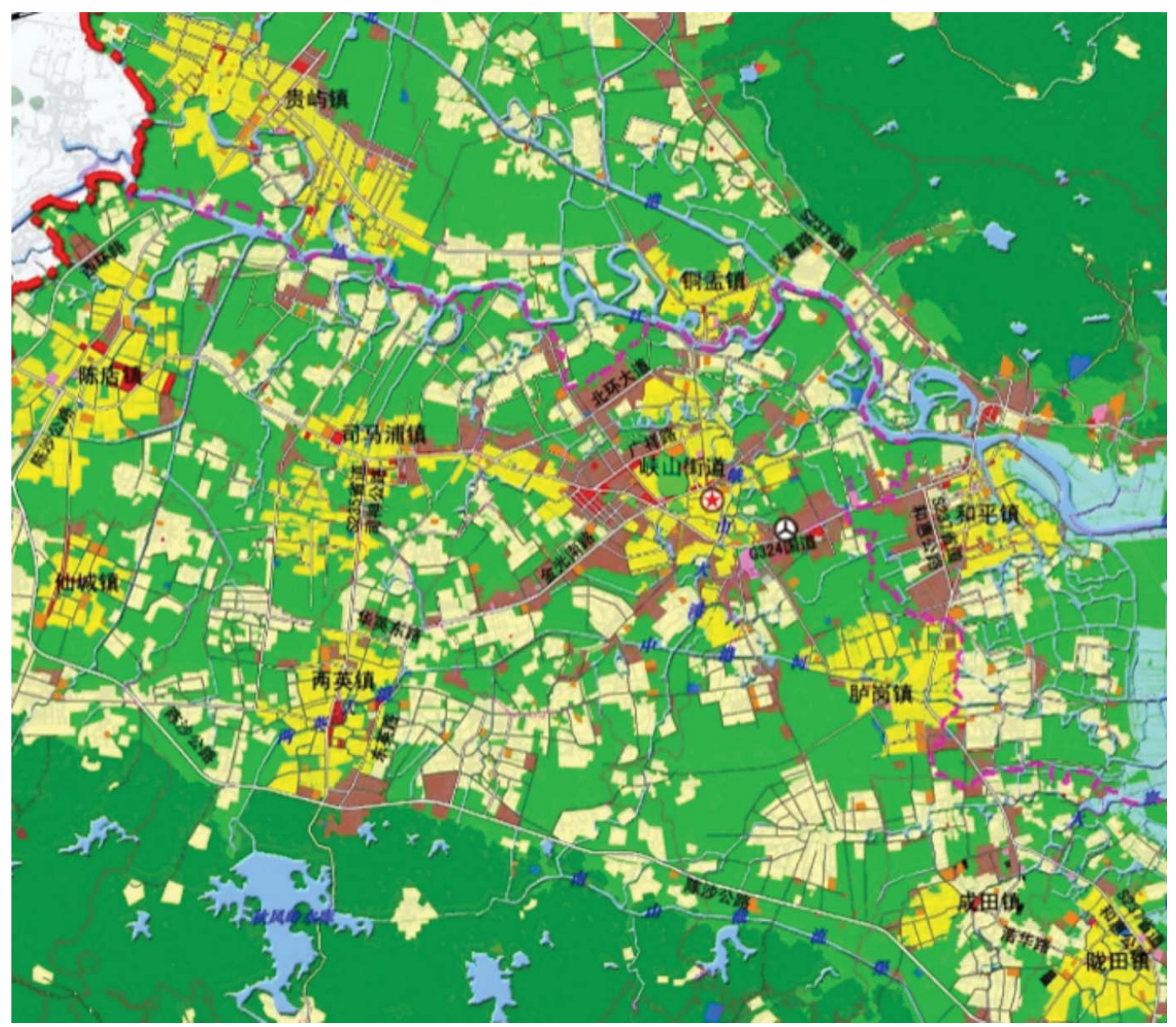

Figure 4 Rural and urban land use mix in southern China (Shantou city). (Color figure available online.)

service delivery reduces the fiscal burden on the municipal government, which virtually ignores the issue of accommodation for rural migrants. Their housing needs are exclusively met by private rentals in the housing market, and they remain spatially segregated from other urban areas (W. Wu 2008).

In contrast to informal development, commodity housing estates present a strong spatial order $(\mathrm{F}$. Wu 2005; He 2013). They are in essence master-planned communities, a term used in Australia to describe new development through packaged design (McGuirk and Dowling 2009). In that context, the type of residence is associated with neoliberal urbanism. The perspective has been applied in the study of Chinese suburban residential areas (Shen and $\mathrm{Wu}$ 2012). It has been shown, however, that gated communities demonstrate a strong characteristic of collectivism inherited from Chinese tradition (Y. S. Huang 2006). In China, they also represent the rising aspiration of middle-class life to style and privacy (Pow 2009; F. Wu 2010a; L. Zhang 2010). These gated communities are often within a larger development zone that is under the management of more entrepreneurial governance.
The development is often zoned into industrial and residential uses, using modern planning principles. Figure 5 shows the pattern of land uses in Beijing ETDZ in Yizhuang, recently scaled up into a new town. The development has been driven by the forces of both market and state.

The contrast between formal and informal housing is quite similar to what has been observed between more orderly European living quarters and organic and mixed indigenous areas in third world cities (Dick and Rimmer 1998). In the Chinese case, though, they are within the same development regime. Table 1 compares formal and informal development in Chinese cities. They are significantly different in terms of spatial forms and features. The state is absent in social provision in informal developments, whereas state entrepreneurialism under development corporations dominates in formal development. For formal development, land finance is part and parcel of urban expansion, but informal development is mainly for rental income and used as a tactic of rural farmers in periurban areas to divert land income from the state through their own supply of rental housing or even 


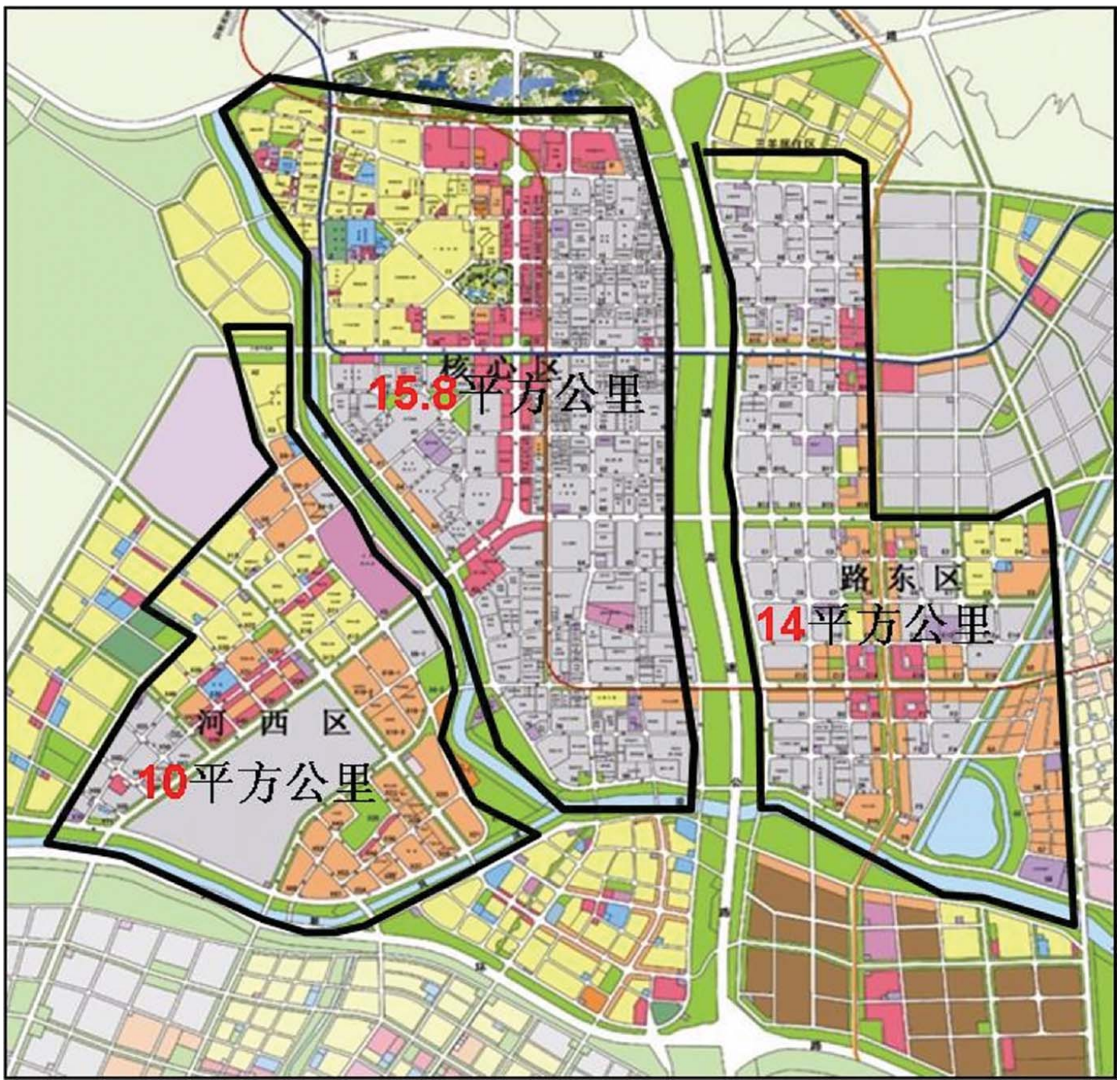

Figure 5 The planning layout of the Beijing Economic and Technological Zone. (Color figure available online.)

illegal sales. Accordingly, there are different governance modes. Formal development has seen growing awareness of property rights and the formation of homeowners' associations. Informal village development is still under village governance and the reformulated market form of villager stockholding companies.

\section{Discussion}

Table 2 shows the understanding of Chinese cities in terms of processes and spatial forms in comparison with global urban studies. First, Chinese urbanization contributes to Western urban research about neoliberalism in general and urban entrepreneurialism in particular.

Table 1 Comparison of formal and informal development in Chinese cities

\section{Formal development}

Spatial forms

Spatial features

The role of the state

Capital accumulation

Governance
Commodity housing estates

Overly designed and packaged

State entrepreneurialism

Land-driven development

Land finance

Homeowners' associations

Property management companies

\section{Informal development}

Urban villages

Irregular uses and spontaneous changes

Absence in social provision

Rural migrants' accommodation

Rental income for property owners

Villagers' committees

Village collectives

Private owners 
Table 2 Comparison of prevailing concepts about the process of urban development and spatial forms and the Chinese cases

\begin{tabular}{|c|c|c|}
\hline & Prevailing concepts & The Chinese cities \\
\hline Neoliberalism & $\begin{array}{l}\text { Ideology } \\
\text { Dominance of the market }\end{array}$ & $\begin{array}{l}\text { Pragmatism } \\
\text { State legitimacy } \\
\text { Hybrid governance }\end{array}$ \\
\hline Marginalization & $\begin{array}{l}\text { Economic restructuring } \\
\text { State retreat } \\
\text { Outcasts }\end{array}$ & $\begin{array}{l}\text { State dominance } \\
\text { Restraining the citizenship claims }\end{array}$ \\
\hline Informality/informal settlements & $\begin{array}{l}\text { "Zones of exception" } \\
\text { Absence of property rights }\end{array}$ & $\begin{array}{l}\text { Urban rural dualism } \\
\text { Complex and void of land management }\end{array}$ \\
\hline Gated communities & $\begin{array}{l}\text { Consumer and lifestyle choice } \\
\text { Private governance } \\
\text { Concern for security }\end{array}$ & $\begin{array}{l}\text { Imaginary lifestyles of suburbia } \\
\text { Place-branding }\end{array}$ \\
\hline Edge cities/postsuburbia & Postindustrial, flexible spaces & $\begin{array}{l}\text { Land-driven development } \\
\text { Land finance } \\
\text { Place creation }\end{array}$ \\
\hline
\end{tabular}

In contrast to an ideology of free market dominance, Chinese local development shows a hybrid form, combining the features of the developmental state with instruments created in the market. Pragmatism is adopted to legitimize the state as a key driver for economic growth. The institutions of land, fiscal policy, and cadre promotion laid down the foundation on which the local state has been incentivized and transformed. Given a very different historical context, it is a surprise to see that Chinese cities demonstrate features remarkably similar to the local competition state but with varying degrees of state persistence. These are noted as neoliberalism with Chinese characteristics (Harvey 2005), localized neoliberalization processes ( $\mathrm{He}$ and $\mathrm{Wu} 2009)$, and state neoliberalism (Chu and So 2012). Despite complaining about the use of neoliberalism (Ong 2007), Chinese urban studies provide a wide middle range of explanations for the dynamism of entrepreneuriallike government behavior, which include the system of cadre promotion, GDP growth mentality, property rights ambiguity, fiscal policy and incentives, and land-based finance. These highlight the various institutional foundations that generate the new process of urban development in China.

Second, marginalization is associated with economic restructuring, globalization, and changing redistributive policies. But Chinese cities show that the process of marginalization does not mean separation from new production processes but rather, as a result of state dominance, the withholding of some citizenship claims. In contrast to the thesis of state retreat and social exclusion, Chinese cities see more state monopolization in resource generation and control and the effects of constraints on citizenship. The delivery of social welfare has been transferred to the local government and through the market as paid services (e.g., for rural migrants to send their children to migrant schools run by companies).

Third, regarding spatial forms, globalization has created immense impacts on Chinese cities. As seen in Southeast Asian cities (Ginsburg, Koppel, and McGee 1991), the spatial form is a mixed pattern of urban and rural land uses described as desakota, a term coined in Indonesia for urban and rural mixes. The concept was applied to the Chinese context by McGee et al. (2007). Informality is described as zones of exception (Roy 2011), applied both to upper market development and to slums. In the former, mafia developers in India (Weinstein 2008) create informality through corruption and bribes as well as their historical influence. Slums are seen as the absence of property rights or ambiguous property rights. The difficulty of enforcing property rights leads to squatter areas. In the Chinese case, informality resulted from the legacy of urban-rural dualism as well as land management complexity. Whereas the desakota model suggests the morphological feature of mixing, the case of Chinese villages shows how development is indeed linked to globalization processes while depending also on unique local land and political institutions.

Fourth, gated communities are seen as the outcome of consumer clubs (Webster, Glasze, and Frantz 2002) and private governance, lifestyle choice, and concern for security (Blakely and Snyder 1997). In the Chinese case, though, the development of gated communities is promoted by developers as a place-branding tactic to enhance the attractiveness of underdeveloped suburbs (F. Wu 2010a). The local government endorses this practice because it helps promote land development, bringing the local government land income. The state is heavily involved in capital mobilization to fund key infrastructure enabling the suburban development of gated communities (Shen and $\mathrm{Wu} 2012$; F. Wu 2015). In this case we see state-led imagineering rather than absence of the state.

Finally, associated with suburban gated communities is the concept of edge cities and postsuburbia, a notion used to describe economic structural changes, the move toward a postindustrial economy, and a flexible space of businesses. In the Chinese case, though, land-driven development has been a key reason for suburban development, with local government, together with planning professionals, playing an important role in place creation. 


\section{Conclusion}

Emerging Chinese cities provide a laboratory to observe planetary urbanization (Brenner 2013). These cities do not represent the model of emerging urbanism but contain some constellated elements of this process. Urban-based accumulation permeates the whole planet, drawing the spaces outside global capitalism into its orbit. Nevertheless, diverse spatial forms persist. The new world-scale development process interacts with historical and existing local structures, which reinforce and reinvent themselves into new market-compatible forms. During the process of remodeling, new properties and features are created. It is in this sense that both the cities themselves and their properties are emergent: neither predefined nor predictable, they reflect contingent social interactions, and open possibilities for more sustainable and just forms.

The notion of emergence has a sense of complexity. It is not a result of the global process that dominates the locality. Emerging Chinese cities show that local institutions are an indispensable part of urban transformation. For example, bukou and state ownership of land have been given a new meaning in the process of market development. Their lasting effects create a new space of informality in Chinese urban villages where rural migrants, subject to bukou, become tenants of private and informal housing. The growth of cities relies highly on the mechanism of the state land monopoly. The state strives to control land and eliminate informality through urban renewal. Rather than being eliminated, however, informality is reinforced, reemerging with its peculiar mode of development as more rural villages are converted into private rentals through self-development (F. Wu, Zhang, and Webster 2013). The renewal process itself must make exceptions for developers to give them viable real estate projects. This is seen in southern China, where intensity and plot ratio have to exceed the city plans or the government has to put aside development controls. The peculiar state dominance in land supply lays down the foundation of this mode of development, known as land-based finance. These are specific geographical processes and spatial forms in China that, together with other examples from other Asian cities and the cities of the Global South, require us to rethink the Western urban theory (Roy 2009). As shown in this article, land-driven urban development and urban village expansion both reveal a wide process of neoliberalization and associated informality.

This article examines emerging Chinese cities as an example of emerging Asia. Chinese cities no doubt demonstrate some special features, but they are not entirely unique. The development of Chinese cities is promoted and intervened by the developmental state, as seen in other East Asian countries. As shown by Glassman (this issue), too much has the nature of the developmental state been associated with the national state while the transnational forces are neglected in the scholarship of Asian development. The emergence of Chinese cities is an outcome of not just the developmental state at the central level and its national development strategies but also the entrepreneurial local state that taps into the market resources to act for its own political and fiscal objectives. In this sense, the Chinese state challenges the dichotomy of the developmental state of authoritarianism and the entrepreneurial state of neoliberalism. Rather, these contradictory characteristics are combined into the emerging property of Chinese state in the new phase of planning for growth $(\mathrm{F}$. $\mathrm{Wu} 2015$ ), in which growth has been pursued to legitimize state dominance. Second, emerging Chinese cities departed from its tradition of the socialist planned economy and demonstrated widespread informality and irregularity in governance, as typically shown in South and Southeast Asian countries (Roy 2011). The introduction of market mechanisms and relaxation of state control mean inevitable creation of unruly spaces. But what is more, as shown in emerging Chinese cities, is that this informality is not simply a result of state incompetence and weak governance. Rather, the informality is a deliberate strategy, not only giving much discretion to developers through exception of governance, for example, in city planning (F. Wu 2015) but also being a practical solution of labor reproduction, as seen self-building in urban villages.

These Chinese studies contribute to the understanding of concrete institutional mechanisms, which are not derivative from but are an integral part of transformation. The changes are both relational (flow and networks) and scalar (decentralization and territorialization). Concrete institutional mechanisms trigger the entrepreneurial-like behavior of the local state, which becomes a market agent. Chinese cities thus prompt us to treat the property of emergence seriously. Rather than caricaturing the Chinese state as an authoritarian regime, the emergence perspective allows us to comprehend how contradictory approaches could be adopted simultaneously: an absence of housing provision to rural migrants as a neoliberal retreat from social provision, aggressive land acquisition by the state-backed development corporations, and place promotion and branding through entrepreneurial strategy, discourse, and action (Jessop and Sum 2000). These are combined to create a version of state entrepreneurialism, as seen in the development of the Beijing ETDZ at Yizhuang: an edge city location (Garreau 1991) that is more a postsuburbia outcome of state entrepreneurialism (F. Wu and Phelps 2011). Similarly, Zhangjiang HighTech Park at Pudong in Shanghai is more than a cluster of urban agglomeration but is driven by state promotion of indigenous innovation capacities (F. Z. Zhang and $\mathrm{Wu}$ 2012) and the formation of a regional innovation system under state guidance (F. Z. Zhang 2015). Without seeing the deeply embedded institutions, there is a temptation to interpret these as yet another edge city or multinational research and development cluster.

As seen in emerging Chinese cities, market transition is not an ideology but a governance technique ( $\mathrm{F}$. $\mathrm{Wu} 2010 \mathrm{~b})$. The introduction of market mechanisms 
and market operational instruments (including commodification and techniques) has intrinsically changed the nature of the developmental state at the national scale. It is thus equally tempting to see emerging Chinese cities as derivative of the entrepreneurial city. As Cochrane (2007) appropriately complained, however, the city is not a firm but a polity and thus subject to political forces. Chinese cities provide a chance to expand the geography of theories (Roy 2009) and, together with other cities in the global south, contribute to global urban studies.

\section{Acknowledgments}

An earlier version of this article was presented at the Presidential Plenary Session of the 2013 Annual Meeting of the Association of American Geographers. I am grateful to Eric Sheppard for inviting me to the session and his advice on the article.

\section{Funding}

This research is supported by the UK Economic and Social Research Council (ESRC)/Department for International Development (DFID) project (RES-167-250448) and the Social Sciences and Humanities Research Council of Canada through funding from the Major Collaborative Research Initiative "Global Suburbanism: Governance, Land, and Infrastructure in the 21st Century (2010-2017)." The usual disclaimers apply.

\section{Literature Cited}

Andrusz, G. M., M. Harloe, and I. Szelenyi, eds. 1996. Cities after socialism: Urban and regional change and conflict in postsocialist societies. Oxford, UK: Blackwell.

Blakely, E. J., and M. G. Snyder. 1997. Fortress America: Gated communities in the United States. Washington, DC: Brookings Institution Press.

Brenner, N. 2013. Theses on urbanization. Public Culture 25 (1): 85-114.

Chien, S. S. 2013. New local state power through administrative restructuring-A case study of post-Mao China county-level urban entrepreneurialism in Kunshan. Geoforum 46:103-12.

Chien, S. S., and I. Gordon. 2008. Territorial competition in China and the west. Regional Studies 42 (1): 31-49.

Chu, Y.-W., and A. Y. So. 2012. The transition from neoliberalism to state neoliberalism in China in the turn of the twenty-first century. In Developmental politics in transition: The neoliberal era and beyond, ed. C. Kyung-Sup, B. Fine, and L. Weiss, 166-87. Basingstoke, UK: Palgrave Macmillan.

Cochrane, A. 2007. Understanding urban policy: A critical approach. Oxford, UK: Blackwell.

Deng, F. 2009. Housing of limited property rights: A paradox inside and outside Chinese cities. Housing Studies 24 (6): 825-41.

Dick, H. W., and P. J. Rimmer. 1998. Beyond the third world city: The new urban geography of South-east Asia. Urban Studies 35 (12): 2303-21.
Duckett, J. 2001. Bureaucrats in business, Chinese-style: The lessons of market reform and state entrepreneurialism in the People's Republic of China. World Development 29 (1): 23-37.

Garreau, J. 1991. Edge city: Life on the new frontier. New York: Doubleday.

Ginsburg, N., B. Koppel, and T. G. McGee, eds. 1991. The extended metropolis: Settlement in transition in Asia. Honolulu: University of Hawaii Press.

Harvey, D. 1989. From managerialism to entrepreneurialism: The transformation in urban governance in late capitalism. Geografiska Annaler 71B (1): 3-18.

. 2005. A brief history of neoliberalism. Oxford, UK: Oxford University Press.

He, S. J. 2013. Evolving enclave urbanism in China and its socio-spatial implications: The case of Guangzhou. Social \& Cultural Geography 14 (3): 243-75.

He, S., and F. Wu. 2009. China's emerging neoliberal urbanism: Perspectives from urban redevelopment. Antipode 41 (2): 282-304.

Hsing, Y.-T. 2006. Land and territorial politics in urban China. China Quarterly 187:1-18.

- 2010. The great urban transformation: Politics of land and property in China. Oxford, UK: Oxford University Press.

Huang, Y. S. 2006. Collectivism, political control, and gating in Chinese cities. Urban Geography 27 (6): 507-25.

Huang, Y. Q. 2008. Capitalism with Chinese characteristics: Entrepreneurship and the state. Cambridge, UK: Cambridge University Press.

Jessop, B., and N. L. Sum. 2000. An entrepreneurial city in action: Hong Kong's emerging strategies in and for (inter)urban competition. Urban Studies 37 (12): 22872313.

Lin, G. C. S. 2014. China's landed urbanization: Neoliberalizing politics, land commodification, and municipal finance in the growth of metropolises. Environment and Planning $A$ 46:1814-35.

Liu, Y., S. He, and F. Wu. 2012. Housing differentiation under market transition in Nanjing, China. The Professional Geographer 64 (4): 554-71.

Logan, J., ed. 2008. Urban China in transition. Oxford, UK: Blackwell.

Ma, L. J. C., and B. Xiang. 1998. Native place, migration and the emergence of peasant enclaves in Beijing. The China Quarterly 155:546-81.

Marcuse, P. 1997. The enclave, the citadel, and the ghetto: What has changed in the post-Fordist U.S. city. Urban Affairs Review 33 (2): 228-64.

McGee, T. G., G. C. S. Lin, A. M. Marton, M. Y. L. Wang, and J. Wu. 2007. China's urban space: Development under market transition. London and New York: Routledge.

McGuirk, P., and R. Dowling. 2009. Neoliberal privatisation? Remapping the public and the private in Sydney's masterplanned residential estates. Political Geography 28 (3): 174-85.

Oi, J. C. 1995. The role of the local state in China's transitional economy. China Quarterly 144:1132-49.

Ong, A. 2007. Neoliberalism as a mobile technology. Transactions of the Institute of British Geographers 32 (1): 3-8.

Po, L. 2012. Asymmetrical integration: Public finance deprivation in China's urbanized villages. Environment and Planning A 44 (12): 2834-51.

Pow, C.-P. 2009. Gated communities in China: Class, privilege and the moral politics of the good life. London and New York: Routledge. 
Qian, Y., and B. R. Weingast. 1997. Federalism as a commitment to preserving market incentives. Fournal of Economic Perspectives 11 (4): 83-92.

Robinson, J. 2011. The travels of urban neoliberalism: Taking stock of the internationalization of urban theory. Urban Geography 32 (8): 1087-1109.

Roy, A. 2009. The 21st-century metropolis: New geographies of theory. Regional Studies 43 (6): 819-30.

- 2011. Slumdog cities: Rethinking subaltern urbanism. International fournal of Urban and Regional Research 35 (2): 223-38.

Roy, A., and A. Ong, eds. 2011. Worlding cities: Asian experiments and the art of being global. Oxford, UK: Wiley-Blackwell.

Shen, J., and F. L. Wu. 2012. The development of masterplanned communities in Chinese suburbs: A case study of Shanghai's Thames Town. Urban Geography 33 (2): 183203.

Solinger, D. J. 2006. The creation of a new underclass in China and its implications. Environment and Urbanization 18 (1): 177-93.

Tao, R., F. B. Su, M. X. Liu, and G. Z. Cao. 2010. Land leasing and local public finance in China's regional development: Evidence from prefecture-level cities. Urban Studies 47 (10): 2217-36.

Tian, L. 2008. The Chengzhongcun land market in China: Boon or bane? A perspective on property rights. International fournal of Urban and Regional Research 32 (2): 282-304.

Tsui, K., and Y. Wang. 2004. Between separate stoves and a single menu: Fiscal decentralization in China. The China Quarterly 177:71-90.

Wacquant, L. 2008. Urban outcasts: A comparative sociology of advanced marginality. Cambridge, UK: Polity.

Walder, A. 1995. Local governments as industrial firms: An organizational analysis of China's transitional economy. American fournal of Sociology 101 (2): 263-301.

Wang, L. 2014. Forging growth by governing the market in reform-era urban China. Cities 41:187-93.

Wang, Y. P., Y. Wang, and J. Wu. 2009. Urbanization and informal development in China: Urban villages in Shenzhen. International fournal of Urban and Regional Research 33 (4): 957-73.

Wank, D. L. 1996. The institutional process of market clientelism: Guanxi and private business in a South China city. The China Quarterly 147:820-38.

Webster, C., G. Glasze, and K. Frantz. 2002. The global spread of gated communities. Environment and Planning $B$ 29 (3): 315-20.

Weinstein, L. 2008. Mumbai's development mafias: Globalization, organized crime and land development. International Fournal of Urban and Regional Research 32 (1): 22-39.

Wu, F. 2003. The (post-) socialist entrepreneurial city as a state project: Shanghai's reglobalisation in question. Urban Studies 40 (9): 1673-98.

- 2004. Urban poverty and marginalization under market transition: The case of Chinese cities. International Fournal of Urban and Regional Research 28 (2): 401-23.
2005. Rediscovering the "gate" under market transition: From work-unit compounds to commodity housing enclaves. Housing Studies 20 (2): 235-54.

. 2010a. Gated and packaged suburbia: Packaging and branding Chinese suburban residential development. Cities 27 (5): 385-96.

2010b. How neoliberal is China's reform? The origins of change during transition. Eurasian Geography and Economics 51 (5): 619-31.

. 2015. Planning for growth: Urban and regional planning in China. London and New York: Routledge.

Wu, F., and N. A. Phelps. 2011. (Post)suburban development and state entrepreneurialism in Beijing's outer suburbs. Environment and Planning $A 43$ (2): 410-30.

Wu, F., F. Z. Zhang, and C. Webster. 2013. Informality and the development and demolition of urban villages in the Chinese peri-urban area. Urban Studies 50 (10): 1919-34.

Wu, W. 2008. Migrant settlement and spatial distribution in metropolitan Shanghai. The Professional Geographer 60 (1): 101-20.

$\mathrm{Xu}, \mathrm{C} .2011$. The fundamental institutions of China's reform and development. Fournal of Economic Literature 49 (4): 1076-1151.

Xu, J., A. Yeh, and F. L. Wu. 2009. Land commodification: New land development and politics in China since the late 1990s. International Fournal of Urban and Regional Research 33 (4): 890-913.

Yang, D. Y. R., and H. K. Wang. 2008. Dilemmas of local governance under the development zone fever in China: A case study of the Suzhou region. Urban Studies 45 (5-6): 1037-54.

Yang, Y.-R. D. 2013. A tale of Foxconn city: Urban village, migrant workers and alienated urbanism. In Rural migrants in urban China: Enclaves and transient urbanism, ed. F. Wu, F. Zhang, and C. Webster, 147-63. London and New York: Routledge.

Zhang, F. Z. 2015. Building biotech in Shanghai: A perspective of regional innovation system. European Planning Studies 23 (10): 2062-78.

Zhang, F. Z., and F. L. Wu. 2012. Fostering "indigenous innovation capacities": The development of biotechnology in Shanghai's Zhangjiang High-Tech Park. Urban Geography 33 (5): 728-55.

Zhang, L. 2010. In search of paradise: Middle-class living in a Chinese metropolis. Ithaca: NY: Cornell University Press.

Zhou, Y., and L. J. C. Ma. 2003. China's urbanization levels: Reconstructing a baseline from the fifth population census. The China Quarterly 173:176-96.

Zhu, J. 2004. Local development state and order in China's urban development during transition. International fournal of Urban and Regional Research 28:424-47.

FULONG WU is Bartlett Professor of Planning at the University College London, Central House, London, WC1H 0NN, UK. E-mail: fulong.wu@ucl.ac.uk. His research interests include urban development in China and its social and sustainable challenges. 